\title{
TELAAH FITOKIMIA EKSTRAK ETANOL DAUN JERUK PURUT (Citrus hystrix DC) DI KABUPATEN KARAWANG
}

\author{
Maya Arfania \\ Program Studi Farmasi Universitas Buana Perjuangan Karawang \\ maya.arfania@ubpkarawang.ac.id
}

\begin{abstract}
Abstrak
Jeruk purut (Citrus hystrix DC.) merupakan salah satu keanekaragaman flora di Indonesia. Jeruk purut oleh masyarakat Indonesia dimanfaatkan sebagai penyedap masakan dan aroma terapi. Penelitian mengenai jeruk purut masih terbatas dilakukan dibandingkan ketersediaan jeruk purut di alam yang melimpah. Penelitian ini bertujuan untuk mengetahui kandungan metabolit sekunder ekstrak etanol daun jeruk purut yang terdiri dari flavonoid, alkaloid, polifenolat, kuinon, monoterpenoid dan seskuiterpenoid.

Penelitian ini dilakukan dengan metode ekstraksi kemudian dianalisis penapisan fitokimia simplisia daun jeruk purut secara kualitatif. Hasil penelitian menunjukkan ekstrak daun jeruk purut positif mengandung senyawa alkaloid, flavonoid, polifenolat, kuinon, monoterpenoid dan seskuiterpenoid.
\end{abstract}

Kata kunci : Daun citrus hystrix, ekstraksi, metabolit sekunder

\section{Abstract}

Lime (Citrus hystrix DC) is one of the flora diversity in Indonesia. Lime has been used as a seasoning and aromatherapy by Indonesian people. Research of lime still limited compared to lime availability which is very rich in the nature. The purpose of the research is to discover the content of ethanol extract of lime leaves which is consist of flavonoids, alkaloids, poliphenolics, quinone, monoterpenoin, and sesquiterpenoin.

The research is conducted with extraction method then the phytochemical screebning of lime leaves simplicia has been analyzed with qualitative methode. The result show that lime leeaves extract positively contain alkaloids, flavonoids, polyphenolics, quinone, monoterpenoid and sesquiterpenoid compound.

Keywords: Citrus hystrix leaves, extraction, secondary metabolite

\section{PENDAHULUAN}

Jeruk purut (Citrus hystrix DC.) merupakan salah satu keanekaragaman flora di Indonesia. Jeruk purut oleh masyarakat Indonesia dimanfaatkan sebagai penyedap masakan dan aroma terapi (Dalimartha, 2006). Penelitian mengenai jeruk purut masih terbatas dilakukan dibandingkan ketersediaan jeruk purut di alam yang melimpah. Menurut penelitian sebelumnya oleh Tunjung (2015) ditemukan bahwa daun jeruk purut mengandung senyawa aktif seperti alkaloid, flavonoid, terpenoid, tanin dan saponin. Penelitian lanjut membuktikan bahwa ekstrak etil asetat dan kloroform daun jeruk purut mempunyai efek sitotoksisitas pada sel kanker serviks, neuroblastoma dan kanker payudara. Selain itu, penelitian yang dilakukan oleh Hutadilok-towatana et al. (2006) menunjukkan bahwa ekstrak daun dan buah jeruk purut memiliki aktivitas antioksidan, antimikrobia, antiinflamasi, dan menangkap radikal bebas. Berdasarkan penelitian-penelitian tersebut menunjukkan bahwa jeruk purut memiliki potensi sebagai kandidat obat herbal terstandar (OHT). 
Tanin merupakan senyawa polifenol kompleks yang dapat ditemukan pada beberapa tanaman. Sama halnya dengan polifenol, tanin juga dapat menunjukkan efek antioksidan dan aktivitas antibakteri. Tanin menghambat pertumbuhan bakteri dan merusak dinding sel sitoplasma yang menyebabkan kerusakan stuktur bakteri secara cepat. Beberapa penelitian sebelumnya telah membuktikan bahwa efek antimikroba tanin yaitu dengan menginaktivasi adhesin mikroba dan enzim hidrolitik sepeti protease dan karbohidrolase dan sel transpot protein. (Dalimartha, 2000).

Minyak atsiri dari jeruk purut memiliki efek antibakteri terhadap beberapa bakteri seperti Propionibacterium acnes, Bacillus, Staphylococcus epidermis, Escerichia coli, Pseudomonas aeruginosa, dan Staphylococcus aureus. Kandungan minyak atsiri dari kulit jeruk purut dapat menghambat respirasi dari sel bakteri. (Dalimartha, 2000).

\section{METODE PENELITIAN}

\section{Bahan}

Bahan - bahan yang digunakan dalam penelitian ini yaitu kulit buah dan daun jeruk purut dari daerah Karawang, Etanol, HPMC (Bratachem), tween 80 (Bratachem), span 80 (Bratachem), propilen glikol, aquadest, etil asetat, n-heksan, silika gel, etanol, metil paraben, propil paraben.

\section{Alat}

Alat yang digunakan dalam penelitian ini adalah seperangkat alat maserator, viskotester Lammy, inkubator (Lammy), oven (Lammy), pH meter (Lammy), neraca analitik (Advanturer Ohaus), spuit injeksi (Terumo), alat-alat gelas (Pyrex $\left.{ }^{\circledR}\right)$, silika gel GF dan lampu UV.

\section{Pembuatan Simplisia}

Daun jeruk purut sebanyak $5 \mathrm{~kg}$ disortasi kering, kemudian dikeringkan menggunakan oven (suhu $45^{\circ} \mathrm{C}$ ) dan dibawah sinar matahari. Setelah itu disortasi kering kembali, disimpan dalam wadah tertutup dan diberi label dan silica gel.

\section{Ekstraksi}

Maserator dilapisi dengan penyaring. Daun jeruk purut sebanyak 250 gram dimasukkan dan ditambah larutan pengekstraksi. Diamkan selama 10 menit, setelah itu tambahkan pelarut sampai simplisia terendam. Diamkan selama 24 jam sambil diaduk. Setelah itu, tampung ekstrak dan ulang ekstraksi sampai diperoleh ekstrak cair. Setelah diperoleh ekstrak cair, pekatkan dengan etanol.

\section{Skrining Fitokimia}

1. Penapisan alkaloid

Simplisia sebanyak 1 gram dihaluskan, kemudian basahi dengan 10\% amonia encer. Tambahkan $5 \mathrm{ml}$ kloroform, lalu masukkan ke dalam tabung reaksi. Tambahkan $\mathrm{HCl} 2 \mathrm{~N}$, kocok kuat, kemudian bagi menjadi 2 bagian. Pada bagian 
pertama, tambahkan pereaksi mayer, sedangkan bagian yang lain tambahkan pereaksi dragondorf.

2. Flavonoid

Tambahkan $50 \mathrm{ml}$ air panas pada 1-2 gram simplisia, kemudian didihkan selama 5 menit, lalu saring. Bagi filtrat menjadi 5 bagian.

3. Polifenolat

Tambahkan serbuk Mg sesepora dan $\mathrm{HCl} 2 \mathrm{~N}$ sebanyak $5 \mathrm{ml}$ ke filtrat falovonoid. Kemudian tambahkan amil alkohol, biarkan memisah. Pada bagian filtrat flavonoid yang lain ditambahkan pereaksi $\mathrm{FeCl} 3$.

4. Tanin

Tambahkan larutan gelatin $1 \%$ pada filtrat flavonoid.

5. Kuinon

Tambahkan larutan $\mathrm{KOH} \mathrm{5 \%} \mathrm{pada} \mathrm{filtrat} \mathrm{falvonoid.}$

6. Saponin

Kocok kuat filtrat falvonoid dalam tabung reaksi selama 10 detik, kemudian tambahkan $\mathrm{HCl}$.

7. Monoterpenoid dan seskuiterpenoid

Gerus 1 gram simplisia, kemudian tambahkan $5 \mathrm{ml}$ eter. Letakkan ke dalam cawan penguap, biarkan menguap hingga kering. Teteskan larutan vanilin 10\% ke dalam asam sulfat pekat, kemudian tambahkan warna-warna.

8. Triterpenoid dan steroid

Letakkan filtrat flavonoid ke dalam cawan penguap, kemudian biarkan menguap hingga kering. Setelah itu teteskan 2-3 tetes pereaksi LB.

\section{HASIL dan PEMBAHASAN}

1. Pembuatan simplisia

\begin{tabular}{|l|l|l|l|l|}
\hline No & \multicolumn{1}{|c|}{ Bahan } & \multicolumn{1}{|c|}{ Perlakuan } & 1 Hasil \\
\hline 1 & $\begin{array}{l}\text { Daun jeruk purut } \\
5 \mathrm{~kg}\end{array}$ & Sortasi basah jeruk purut basah \\
\hline 2 & $\begin{array}{l}\text { Daun jeruk purut } \\
\text { basah 1 kg }\end{array}$ & Dikeringkan & $\begin{array}{l}\text { Dengan jinar } \\
\text { matahari selama 18 } \\
\text { hari } \pm 48 \text { jam } \\
\text { Dengan oven } \pm 16 \text { jam } \\
\text { dengan suhu 45 }\end{array}$ & $\begin{array}{l}\text { Simplisia daun jeruk purut } \\
\text { sebanyak 200 g }\end{array}$ \\
\hline 3 & $\begin{array}{l}\text { Simplisia daun } \\
\text { jeruk purut 200 } \\
\mathrm{g}\end{array}$ & $\begin{array}{l}\text { Sortasi kering dan disimpan dalam } \\
\text { wadah tertutup } \\
\text { silica gel }\end{array}$ & Simplisia daun jeruk purut \\
\hline
\end{tabular}

2. Maserasi daun jeruk purut

\begin{tabular}{|c|c|c|}
\hline Hari ke - & Berat simplisia yang digunakan & Berat hasil ekstrak \\
\hline 1 & \multirow{5}{*}{ Masing - masing $200 \mathrm{~g}$} & $350 \mathrm{ml}$ \\
\hline 2 & & $300 \mathrm{ml}$ \\
\hline 3 & & $200 \mathrm{ml}$ \\
\hline 4 & & $200 \mathrm{ml}$ \\
\hline 5 & & $290 \mathrm{ml}$ \\
\hline & Jumlah & 1340 \\
\hline
\end{tabular}


3. Skrining fitokimia

\begin{tabular}{|c|c|c|c|}
\hline No & Golongan senyawa & Hasil (+/-) & Keterangan \\
\hline 1 & Alkaloid & + & Terbentuk endapan putih dan keruh \\
\hline 2 & Flavonoid & + & Terbentuk endapan kuning \\
\hline 3 & Polifenolat & + & $\begin{array}{l}\text { Terbentuk endapan hitam tidak } \\
\text { terlalu pekat }\end{array}$ \\
\hline 4 & Tannin & - & Tidak terbentuk endapan putih \\
\hline 5 & Kuinon & + & $\begin{array}{l}\text { Terbentuk warna kuning } \\
\text { kemerahan }\end{array}$ \\
\hline 6 & Saponin & - & Tidak terbentuk busa \\
\hline 7 & $\begin{array}{l}\text { Monoterpenoin dan } \\
\text { sesquiterpenoid }\end{array}$ & + & $\begin{array}{l}\text { Terbentuk warna-warna hijau hitam } \\
\text { kebiruan }\end{array}$ \\
\hline 8 & $\begin{array}{l}\text { Triterpenoid dan } \\
\text { steroid }\end{array}$ & - & Tidak terbentuk warna biru - ungu \\
\hline
\end{tabular}

Daun jeruk purut yang digunakan untuk membuat simplisia sebanyak $5 \mathrm{~kg}$. Pembuatan simplisia melalui beberapa tahap yaitu sortasi basah, pengeringan, dan sortasi kering. Sortasi basah dilakukan untuk memisahkan kotoran dan bahan asing. Selanjutnya bahan simplisia dikeringkan menggunakan oven \pm 16 jam dengan suhu $45^{\circ} \mathrm{C}$ dan sinar matahari slama 18 hari \pm 48 jam. Sebelum dilakukan ekstraksi dan skrining fitokimia serta fraksinasi, terlebih dahulu dibuat simpilisa dari daun jeruk purut. Adapun dari $1 \mathrm{Kg}$ basah daun jeruk purut, didapat simplisia daun jeruk purut sebanyak 200 gram. Pengeringan dilakukan menggunakan dua cara, yaitu menggunakan oven dan sinar matahari. Pengeringan dengan sinar matahari memberikan hasil yang lebih baik daripada pengeringan dengan oven, terlihat dari perbedaan warna yang terjadi (warna hijau kecoklatan pada pemanasan dengan sinar matahari). Sedangkan hasil pengeringan dengan oven, warna yang terjadi adalah hijau agak kecoklatan tua.

\section{KESIMPULAN}

Hasil dari skrining fitokimia menunjukan dalam daun jeruk purut positif mengandung alkaloid, flavonoid, polifenolat, kuinon, serta monoterpenoid dan seskuiterpenoid.

\section{DAFTAR PUSTAKA}

Agusta, A. 2000. Minyak Atsiri Tumbuhan Tropika Indonesia. Bandung : ITB.

Backer, C. A., \& Van Den Brink, B. R. C. 1968. Flora of Java, Vol.III, 94, 107, 109. Netherland: HNP Noordhoff Groningen.

Berghe, D.A.V. \& A.J. Vlietinck. 1991. Screening methods for antibacterial and antiviral agent from higher plants In : Assays for Bioactivity (Hostettmann K.Ed) Vol.6. Methods in plant biochemistry (Dey, P.M. and J.B. Harborne Ed): London : Academic Press, 47.

Dalimartha, S. 2000. Atlas Tumbuhan Obat Indonesia II. Niaga Swadaya. Jakarta. Dalimartha, S. 2006. Atlas Tumbuhan Obat Indonesia II. Niaga Swadaya. Jakarta.

Guenther, E. 1990. Minyak Atsiri Jilid III A Terjemahan Oleh Kateren, S. Jakarta UI Press. 
Koswara, S. 2009. Menyuling dan Menepungkan Minyak Asiri Daun Jeruk Purut http://www.ebookpangan.com/artikel/menyuling\%20dan 20menepungkan $\% 20$ minyak\%20asiri.pdf [diakses tanggal 10 Februari 2010]. 